\title{
Anatomical and Topographical Description of the Digestive System of Caiman crocodilus (Linnaeus 1758), Melanosuchus niger (Spix 1825) and Paleosuchus palpebrosus (Cuvier 1807)
}

\author{
Descripción Anatómica y Topográfica del Sistema Digestivo del Caimam crocodillus \\ (Linnaeus 1758), Melanosuchus niger (Spix 1825) y Paleosuchus palpebrosus (Cuvier 1807)
}

"Mariluce Ferreira Romão; *André Luiz Quagliatto Santos; **Fabiano Campos Lima; *Simone Salgueiro De Simone; "Juliana Macedo Magnino Silva; "Líria Queiroz Hirano; ${ }^{* * *}$ Lucélia Gonçalves Vieira \& *José Guilherme Souza Pinto

\begin{abstract}
ROMÃO, M. F.; SANTOS, A. L. Q.; LIMA, F. C.; DE SIMONE, S. S.; SILVA, J. M. M.; HIRANO, L. Q.; VIEIRA, L. G. \& PINTO, J. G. S. Anatomical and topographical description of the digestive system of Caiman crocodilus (Linnaeus 1758), Melanosuchus niger (Spix 1825) and Paleosuchus palpebrosus (Cuvier 1807). Int. J. Morphol., 29(1):94-99, 2011.
\end{abstract}

SUMMARY: This paper describes the digestive system of Caiman crocodilus, Melanosuchus niger and Paleosuchus palpebrosus based on anatomical and topographical inferences. The study involves two digestive systems of $C$. crocodilus, one of $M$. niger and one of P. palpebrosus, already fixed in $10 \%$ formaldehyde, belonging to the collection of the Wild Animal Research Laboratory (LAPAS) of the Federal University of Uberlândia. The work begins with a description of the digestive system of the aforementioned crocodilians, followed by topographical associations, aided by photographs taken with a SONY® DSC-H20 camera, X-rays of the gastrointestinal tract and a photograph of the digestive system of $C$. crocodilus prior to formaldehyding, which also belong to the LAPAS collection. The results indicate that the digestive system of crocodilians consists of a wide mouth, short pharynx, long straight esophagus, dilated stomach in relation to the rest of the tract, pancreas lodged between the first two ventral duodenal loops, coiled small intestine, large intestine with diameter larger than the preceding segments, and cloaca as the terminal portion of the digestive, urinary and reproductive systems. The anatomical and topographical description of the digestive system of $C$. crocodilus (Linnaeus, 1758) (Crocodylia: Alligatoridae), M. niger (Spix, 1825) (Crocodylia: Alligatoridae) and P. palpebrosus (Cuvier, 1807) (Crocodylia: Alligatoridae) can be extended to the other crocodilians due to interspecies and intraspecific behavioral similarities.

KEY WORDS: Anatomy; Alimentary canal; Jacaré paguá; Jacaré tinga; Jacaré açu.

\section{INTRODUCTION}

The digestive system of vertebrates presents structural and functional adaptations to their diverse alimentary habits. In addition to the well defined conformational aspects of herbivores and carnivores, plasticity is a present and predisposing factor (Secor, 2005).

The evolutionary process of reptiles resulted in anatomical and physiological differences in the various systems of the organism, with greater variations of the gastrointestinal tract, making veterinary diagnostics difficult (Mitchell \& Diaz-Figueroa, 2005). This tract is a specialized tube divided into anatomical regions that begin with the mouth and end at the anus (Mackie, 2002).
The gastrointestinal tract of caimans is composed of a mouth, esophagus, stomach, small intestine and large intestine without a cecum (Mader, 2006). The amount of food intake per week is on average $7 \%$ of the live weight of adult animals in captivity (Santos et al., 1997).

The large mouth of reptiles enables them to catch whole prey or large pieces of food and swallow them whole. Mechanical and enzymatic mechanisms then come into play, transforming the food into nutrients for the animal's tissues, while the remains are eliminated (Fernandes, 1981, McIlhenny, 1935; Leonardi et al., 2002; Bernarde, 2003).

\footnotetext{
* Laboratory for Teaching and Research on Wild Animals - limpets, Faculty of Veterinary Medicine, Federal University of Uberlandia, Brazil.

${ }^{*}$ Federal University of Goias, Brazil.

"Federal University of Brasilia, Brazil.
} 
ROMÃo, M. F.; SANTOS, A. L. Q.; LIMA, F. C.; DE SIMONE, S. S.; SILVA, J. M. M.; HIRANO, L. Q.; VIEIRA, L. G. \& PINTO, J. G. S. Anatomical and topographical description of the digestive system of Caiman crocodilus (Linnaeus 1758), Melanosuchus niger (Spix 1825) and Paleosuchus palpebrosus (Cuvier 1807). Int. J. Morphol., 29(I):94-99, 2011.

C. crocodilus, M. niger and P. palpebrosus are crocodilians native to South America, which belong to the class Reptilia, order Crocodylia, and family Alligatoridae (SBH, 2009).

The objective of this study was to describe the digestive system of two specimens of $C$. crocodilus, one of $M$. niger and one of $P$. palpebrosus by means of anatomical and topographical inferences. This description should enable a better understanding of the digestive processes in these animals, contributing to physiological, pathological and phylogenetic studies and to the management and conservation of crocodilians, and extend to their preventive and therapeutic medicine.

\section{MATERIAL AND METHOD}

Two digestive systems of $C$. crocodilus (Linnaeus, 1758) (Crocodylia: Alligatoridae), one of M. niger (Spix, 1825) (Crocodylia: Alligatoridae), and one of P. palpebrosus (Cuvier, 1807) (Crocodylia: Alligatoridae), already fixed in $10 \%$ formaldehyde, from the collection of the Wild Animal Research Laboratory (LAPAS) of the Federal University of Uberlândia, were used in this study.

A description was first made of the digestive system of these crocodilians, followed by topographical associations, aided by photographs taken with a SONY® DSC-H20 camera, X-rays of the gastrointestinal tract and a photograph of the digestive system of C. crocodilus prior to formaldehyding, which also belong to the LAPAS collection.

\section{RESULTS AND DISCUSSION}

Liver. The liver, bilobed and with a conical shape, is located cranially in the coelomic cavity. The right lobe is larger than the left lobe, the former touching the gall bladder and the first two loops of the duodenum and the latter touching the cranial surface of the stomach. The medial dorsal and caudal region of the right lobe contains the hepatic hilum and a piriform gall bladder, which receives a hepatic duct and sends out another duct to the pancreas, as well as a connection linked directly to the pancreas, which bifurcates close to the hilum. It should be noted that these ducts precede the pancreatic ducts, which in turn unite to form the hepatopancreatic ampulla, perforating the duodenum through the duodenal papilla. Leite \& Pessoa (2008) describe interconnections between the liver, gall bladder, pancreas and duodenum of avian digestive systems, such as the hepatocystic, enterocystic and enterohepatic systems, which reveal strong similarities with the crocodilians of this study in view of the taxonomic characteristics these animals share. It should be noted that the relationship between birds and dinosaurs is still under extensive investigation (Ruben et al., 2003; Mader).

On the other hand, with regard to reptiles, Messer (1938), Hickman (1967) and Baroudi (1970), and with regard to the majority of vertebrates, Romer \& Parsons (1985) and Hildebrand (1995), state that the biliary ducts responsible for draining bile from the hepatic lobes unite to form the main right and left ducts, which, together with the cystic duct, form the choledoc duct that opens into the initial portion of the duodenum.

Pancreas. The pancreas is lodged between the first two dorsal duodenal loops, one ascending cranially and the other descending caudally, projecting immediately after the first lateral flexure to the right of the pyloric region is from the pylorus, as in Pseudemys scripta (Miller \& Lagios, 1970).

The pancreas extends dorsally without touching the spleen directly at its terminal segment, since the latter is attached to the medial edge of the descending duodenal flexure, differing from the description of Alligator mississippiensis in the direct final connection to the spleen according to Miller \& Lagios.

Tongue. The tongue is flat, triangular, with lingual papillae covering the dorsal surface from the root to the tip. Santos (1997) describes the tongue of crocodilians as having no significant movement and practically no function in the ingestion of food, being devoid of gustatory buds.

Esophagus. The esophagus is a straight tubular organ located caudally to the short pharynx, dorsally to the trachea, passing between the main bronchi of the trachea and the right and left lungs, and ending cranially in the stomach along the median line, as described by Santos for crocodilians and Sartori (2009) for Hemidactylus mabouia.

The esophageal wall of the species examined in this study appears to be predominantly muscular, indicating a similarity to studies on Alligator mississippiensis, which apply to the other crocodilians and mammals, but differing from the latter by its greater thickness (Skoczylas, 1978; Harding, 1999; Theodoropoulos \& Ledford, 2000; Uriona et al., 2005). Internally, the wall shows creases arranged longitudinally, which sometimes bifurcate or converge.

The middle third of the esophagus is clearly dilated and its wall is thinner due to the passage of large food items ingested by crocodilians, as reported by Santos. 


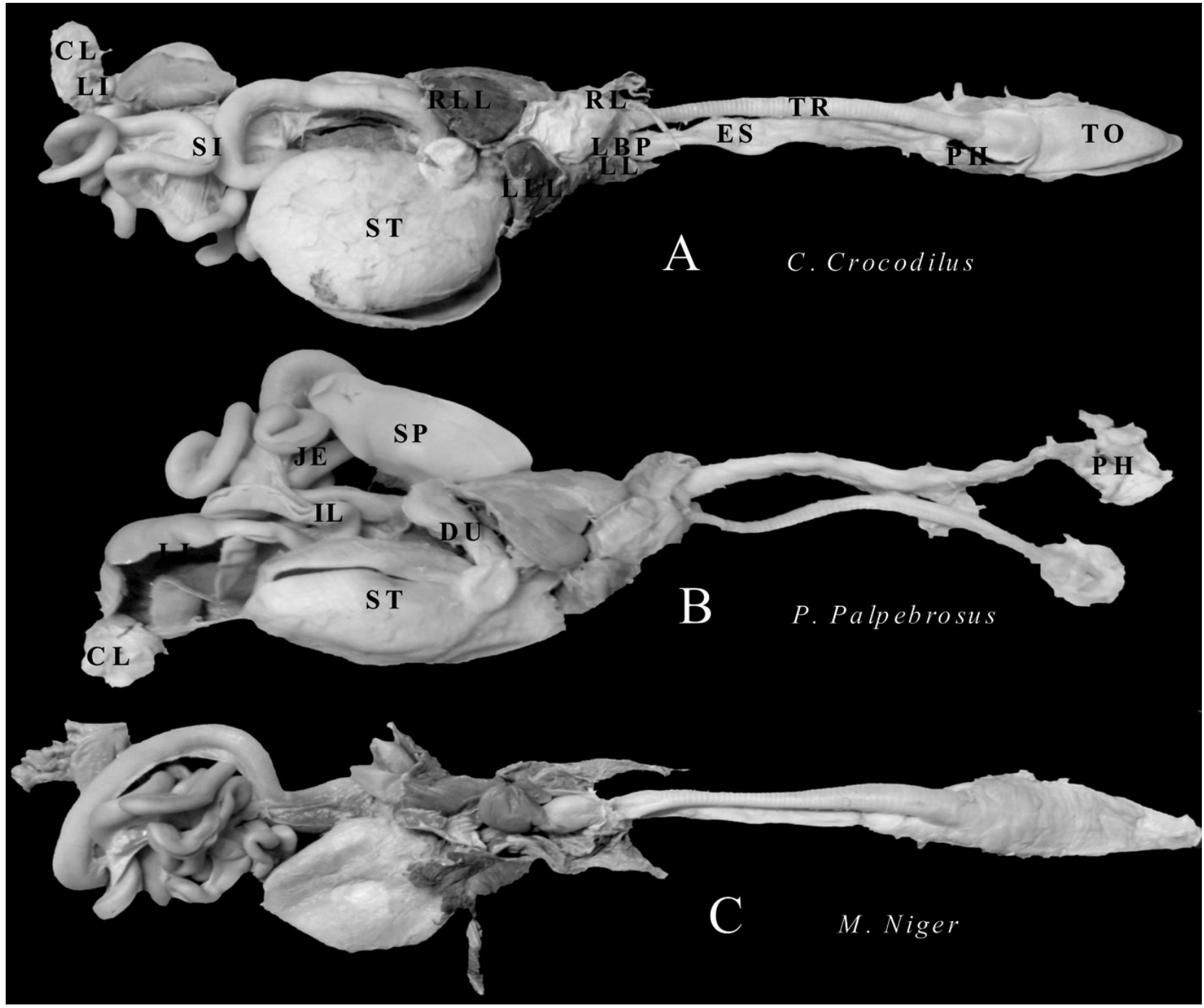

Fig. 1. Digestive system of specimens of C. crocodilus, P. palpebrosus and M. Niger from the LAPAS collection. Ventral views. A - C. crocodilus: TO, tongue; PH, pharynx; TR, trachea; ES, esophagus; RL, right lung; LL, left lung; LPB, left primary bronchus; RLL, right lobe of liver; LLL, left lobe of liver; ST, stomach; SI, small intestine; LI, large intestine; CL, cloaca. B - P. palpebrosus. PH, pharynx; ST, stomach; SP, spleen; DU, duodenum; JE, jejunum; IL, ileum; LI, large intestine; CL, cloaca. C - M. Niger.

The longitudinal creases in the proximities of the gastroesophageal transition zone broaden and become less numerous, and the region becomes more constricted, as reported by Parsons \& Cameron (1977), indicating highly variable possibilities among species such as crocodilians, lizards and chelonians. In this study we also observed intraspecific differences with respect to the number and arrangement of the aforementioned creases.

Stomach. The main portion of the stomach is located in the left antimere in a horizontal circumvallated projection, and not immediately in the aforementioned antimere in an elongated and longitudinal projection, as in Hemidactylus mabouia. Located between the esophagus and the duodenum, it represents the most dilated part of the gastrointestinal tract, and is indicated by Sartori (2009) as the principal site of digestion in crocodilians and by Romer (1973), Orr (1986) and Storer (1986) as functionally similar to the muscular stomach, or gizzard, of birds. It has a large chamber with ventral and dorsal walls of the same thickness, differing from the description given by Wallach (1971), who stated that the stomach of Caiman yacare is divided into two distinct chambers, a thick-walled anterior one and a thin-walled posterior one, without specifying an intermediary delimitation. 
ROMÃO, M. F.; SANTOS, A. L. Q.; LIMA, F. C.; DE SIMONE, S. S.; SILVA, J. M. M.; HIRANO, L. Q.; VIEIRA, L. G. \& PINTO, J. G. S. Anatomical and topographical description of the digestive system of Caiman crocodilus (Linnaeus 1758), Melanosuchus niger (Spix 1825) and Paleosuchus palpebrosus (Cuvier 1807). Int. J. Morphol., 29(1):94-99, 2011.

However, some authors have reported different stomach shapes in several reptiles, such as the U-shape of Iguana iguana (a herbivore) (Smith et al., 2001), and the J-shape of anuran amphibians such as Hemidactylus mabouia (Duellman \& Trueb, 1985; Santana \& Menin, 1994; Castro, 1985).

Four distinct gastric regions are visible: the cardia (small, and corresponding to the cranial end of the stomach, sequent to the gastroesophageal transition zone), the fundus (to the left of the cardiac region, forming a conspicuous cranial angle), the corpus (the region with the largest diameter and length), and the pyloric chamber (the terminal region of the stomach, which ends in the pyloric sphincter), as described by Mitchell \& Diaz-Figueroa (2005) for reptiles. These authors also state that the cardiac region may be large or small, and that the convoluted longitudinal creases found in the stomach lumen - except in the pyloric region due to the greater constriction at its terminal end - may or may not be present, which is consistent with the observations of this study. Sartori (2009) divides the stomach of Hemidactylus mabouia into an oral fundic, an aboral fundic and a pyloric region, while Romer (1973), Orr and Storer divide the stomach of crocodilians into a fundic and a pyloric region.

In the gastroduodenal transition zone the pyloric sphincter is visibly constricted, as reported by Santos and Chiasson (1962), allowing for passage to the duodenum only of liquid or pasty food that has already

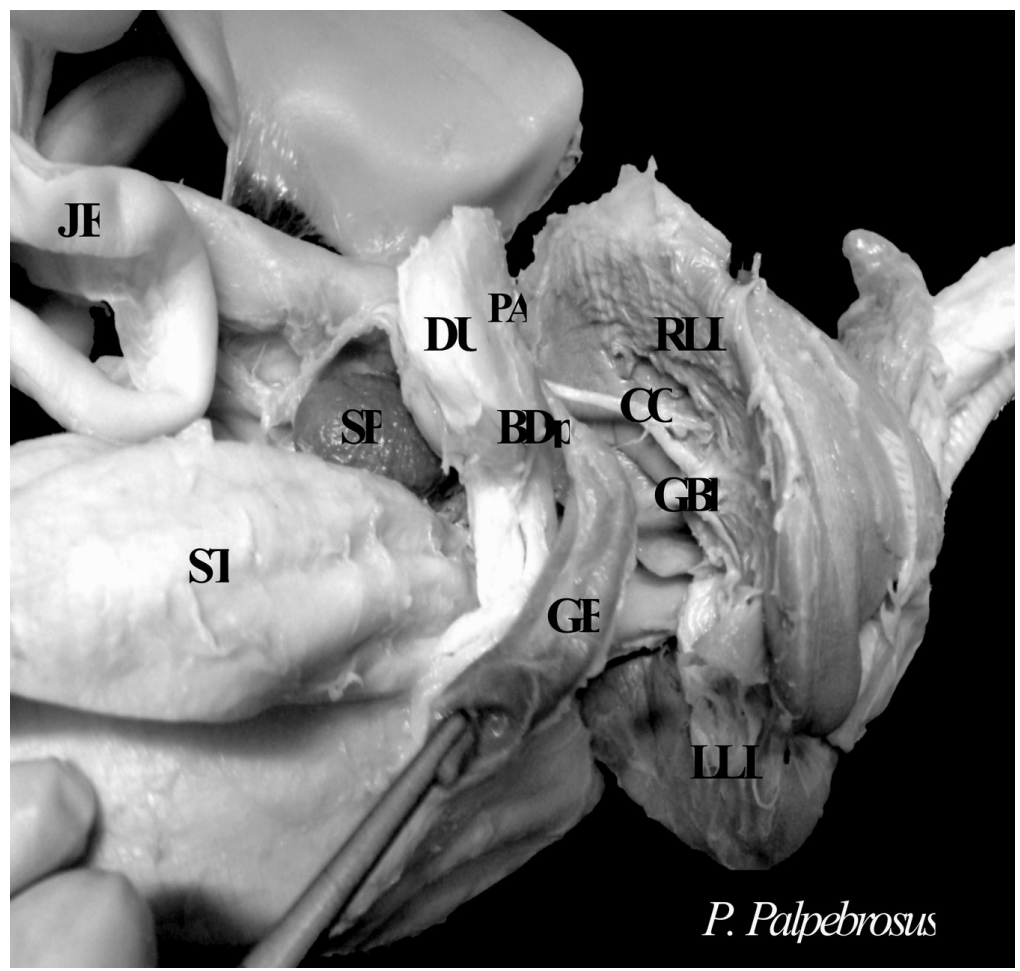

Fig. 2. Digestive system of a P. palpebrosus specimen from the LAPAS collection. Dorsal views. RLL, right lobe of liver; LLL, left lobe of liver; $\mathrm{CO}$, direct connection of the liver to the pancreas; BDp; biliary duct emptying into the pancreas; GBl, gallbladder duct emptying into the liver; PA, pancreas; GB, gall bladder; ST, stomach; DU, duodenum; JE, jejunum; SP, spleen. been neutralized by mucous glands in the pyloric region.

Small Intestine, Large Intestine and Cloaca. Starting from the pyloric sphincter, the small intestine coils through the medial and caudal segments of the coelomic cavity, ending in the large intestine. The small intestine is divided into three segments: the duodenum, jejunum and ileum, which are continuous and devoid of a macroscopic delimitation. These segments are identified through topographical inferences and their progressively diminishing villosity, according to the general description by Santos for crocodilians.

The duodenum begins in the right antimere lateral to the stomach. Its diameter decreases progressively along its length, with a winding projection constricted at some levels, lodging the pancreas between two well defined loops that touch the liver directly and that begin after a short transverse projection, as described by Stahl (2003) in studies on Alligator mississippiensis.

The wall of the small intestine is visibly thicker in the duodenum, presenting several villosities in its internal anatomy, which indicate greater adsorption capacity. These villi decrease progressively toward the caudal portion of the ileum, which is consistent with Leonardi et al. (2002) descriptions of the intestine of reptiles. Secor describes these projections as being more prominent during absorption and diminished after complete digestion, while Stark (2005) gives a superficial description of a similar occurrence with respect to food in the jejunum.

The diameter of the large intestine is about three times larger than that of the small intestine, with a dilated wall tending toward collapsibility. The large intestine of $\mathrm{P}$. palpebrosus has a clearly demarcated crease near the cloaca, unlike the other crocodilians studied here, in which this region is visibly smooth and continuous. It is less thick than the initial segment of the small intestine and thicker than the terminal portion immediately cranial to the large intestine. The large intestine is separated from the small intestine by a sphincter, as described by Wallach (1971). 
ROMÃO, M. F.; SANTOS, A. L. Q.; LIMA, F. C.; DE SIMONE, S. S.; SILVA, J. M. M.; HIRANO, L. Q.; VIEIRA, L. G. \& PINTO, J. G. S. Anatomical and topographical description of the digestive system of Caiman crocodilus (Linnaeus 1758), Melanosuchus niger (Spix 1825) and Paleosuchus palpebrosus (Cuvier 1807). Int. J. Morphol., 29(1):94-99, 2011.

The cloaca is located at the shared end of the digestive, urinary and genital systems. The longitudinal creases extending along its inner wall ensure considerable distension capacity, according to Santos.

The findings of this study demonstrate that the anatomical and topographical description of the digestive system of C. Crocodilus, M. niger and P. palpebrosus can be extended to the other crocodilians, in view of the well known interspecies and intraspecific behavioral similarities found in this study.

In conclusion, morphological studies are important for understanding the digestive processes, underpinning not only physiological, pathological and phylogenetic studies but also the management and conservation, and the preventive and therapeutic medicine of these animals.

ROMÃO, M. F.; SANTOS, A. L. Q.; LIMA, F. C.; DE SIMONE, S. S.; SILVA, J. M. M.; HIRANO, L. Q.; VIEIRA, L. G. \& PINTO, J. G. S. Descripción anatómica y topográfica del sistema digestivo del Caimam crocodillus (Linnaeus 1758), Melanosuchus níger (Spix 1825) y Paleosuchus palpebrosus (Cuvier 1807). Int. J. Morphol., 29(1):94-99, 2011.

RESUMEN: Mediante comparaciones anatómicas y topográficas describimos el sistema digestivo de C. crocodillus, $M$. nigeri y P. palpebrosus. Se utilizaron dos sistemas digestivos de C. crocodillus, uno de M. nigeri y uno de P. palpebrosus, fijados en formalina al $10 \%$ y pertenecientes al laboratorio de enseñanza e investigación de fauna silvestre (LAPAS) de la Universidade Federal de Uberlândia. En primera instancia se realizó la descripción del sistema digestivo de las mencionadas especies, seguido de comparaciones topográficas. Luego, fueron tomados registros fotográficos con cámara DSC H20 SONY. Adicional a esto, nos apoyamos con radiografías del tracto gastrointestinal y fotografías del sistema digestivo de $C$. crocodillus antes de ser fijados en formalina. Los resultados demuestraron que el sistema digestivo de estas tres especies de caimanes está constituido por una boca grande, faringe corta, esófago alargado y rectilíneo, estómago dilatado con relación a las otras partes del tracto digestivo, páncreas alojado entre las dos primeras curvaturas duodenales ventrales, intestino delgado plegado, intestino grueso con un diámetro mayor en relación a los segmentos anteriores y una cloaca donde también terminan los sistemas urinarios y reproductor. La descripción anatómica y topográfica del sistema digestivo de C. crocodillus, $M$. niger y $P$. palpebrosus puede ser extrapolada para otros cocodrilos por la semejanza comportamental interespecies e intraespecíficas.

PALABRAS CLAVE: Anatomía; Tracto alimenticio; Jacaré paguá; Jacaré tinga; Jacaré acu.

\section{REFERENCES}

Bernarde, P. S. Sistema digestório dos répteis. Disponível em: <http\lwww. herpetofauna. hpg.ig. com.br/Pages/ SistemaDigestório>. Acesso em: 07 jun. 2003.

Baroudi, R. Elementos de Zoologia. $6^{\text {a }}$ ed. São Paulo, Nobel, 1970. p.p. $125-52$

Castro, J. C. Anatomo-histologia funcional do tubo digestivo de rã-touro (Rana castebeiana Shaw, 1802). Tempo de passagem do alimento pelo trato digestivo da rã e desenvolvimento de um método de determinação dos valores energéticos de alimentos utilizados em rações de rãs. Tese de Doutorado, Viçosa, Universidade Federal de Viçosa, 1985. pp.210.

Chiasson, R. B. Laboratory Anatomy of the Alligator. Iowa, W.M.C. Brown Company Pub., 1962. p.p.36.

Duellman, W. E. \& Trueb, L. Biology of anphifians. New York, McGraw-Hill, 1985. p.p. 160.

Fernandes, V. Zoologia. $7^{\mathrm{a}}$ ed. São Paulo, Pedagógica e Universitária, 1981.
Harding, S. M. Nocturnal asthma: role of nocturnal gastroesophageal reflux. Chronobiol. Int., 16:641-62, 1999.

Hickman, C. P. Princípios de zoología. Barcelona, Ariel, 1967. pp.505.

Hildebrand, M. Análise da estrutura dos vertebrados. $3^{\mathrm{a}}$ ed. São Paulo, Atheneu, 1995. p.p. 323-8.

Leite I. \& Pessoa C. A. Digestão nas aves II. Animal exótico, Carnaricultura Tuga, 2008.

Leonardi, L.; Grazioli O.; Mechelli L. \& Frye, F. L. Gastric mucinous adenocarcinoma in a diamond python (Morelia spilotes spilotes). Proc. Arav. Reno, NV, 2002. p.p. 63.

Mackie, R. Mutualistic fermentative digestion in the gastrointestinal tract: diversity and evolution. Integr. Comp. Biol., 42:319-26, 2002.

Mader, D. R. Reptile Medicine and Surgery. California, W. B. Saunders Company, 2006. p.p. 1242. 
ROMÃo, M. F.; SANTOS, A. L. Q.; LIMA, F. C.; DE SIMONE, S. S.; SILVA, J. M. M.; HIRANO, L. Q.; VIEIRA, L. G. \& PINTO, J. G. S. Anatomical and topographical description of the digestive system of Caiman crocodilus (Linnaeus 1758), Melanosuchus niger (Spix 1825) and Paleosuchus palpebrosus (Cuvier 1807). Int. J. Morphol., 29(1):94-99, 2011.

McIlhenny, E. A. The alligator's life history. Boston, The Christopher's Publishing House, 1935. p.p. 177.

Messer, H. M. An introduction to vertebrate anatomy. New York, The Macmillan Company, 1938. p. 206-8.

Mitchell \& Diaz-Figueroa. Clinical Reptile Gastroenterology. Vet. Clin. North Am. Exot. Anim.Pract., 8:277-98, 2005.

Miller, M. R. \& Lagios, M. The pancreas. In: Gans C. \& Parsons T. C. (ed.) Biology of the reptilia. New York, Academic Press, 1970. v. 3. pp. 319-46.

Orr, R. T. Biologia dos Vertebrados. São Paulo, Roca, 1986. p.p. 508.

Parsons, T. S. \& Cameron, J. E. Internal relief of the digestive tract. In: Gans C., Parsons T. S., (ed.) Biology of the reptilian, London, Morphology E. Academic Press. V. 6. p.p. 159-223, 1977.

Romer, A. S. \& Parsons, T. S. Anatomia comparada dos vertebrados. $5^{\mathrm{a}}$ ed. São Paulo, Atheneu,. p.p. 338-58. 1985.

Romer, A. S. Anatomía Comparada: Vertebrados. México, Interamericana, 1973. p. 435.

Ruben, J. A.; Jones, T. D. \& Geist N. R.. Respiratory and reproductive paleophysiology of dinosaurs and early birds. Physiol. Biochem. Zool., 76(2):141-64. 2003.

Santana, M. A. \& Menin, A. Anatomia funcional do aparelho digestivo de Leptodactylus labyrinthicus Spix, 1824 (Amphibia, Anura, Leptodactylidae). Rev. Ceres, 41:138-67, 1994.

Santos, S. A. Dieta e nutrição de crocodilianos. EMBRAPACPAP, Corumbá. 1997.

Sartori, S. S. R. Morfologia do tubo digestivo da Lagartixa Hemidactilus mabouia (Moreau de Jonnéz, 1818) (SQUAMATA: GEKKONIDAE). Tese, Viçosa, MG, Universidade Federal de Viçosa, 2009. pp.109.

SBH - Sociedade Brasileira de Herpetologia. Lista de répteis do Brasil. São Paulo. Disponível em: <http:// www.sbherpetologia.org.br/checklist/ repteis.htm>acesso em 20 jul. 2009.

Smith, D.; Dondson, H. \& Spence, E. Gastrointestinal studies in the green iguana: technique and reference values. Vet. Radiol. Ultrasound., 42(6):515-20. 2001.
Secor, S. M. Evolutionary and cellular mechanisms regulating intestinal performance of amphibians and reptiles. Integr. Comp. Biol., 45:282-94, 2005.

Stahl, S. J. Diseases of the reptile pancreas. Vet. Clin. North Am. Exot. Anim. Pract., 6:191-212, 2003.

Starck, J. M. Structural flexibility of the digestive system of tetrapods-Patterns and processes at the cellular and tissue level. In: Physiological and Ecological Adaptations to Feeding in Vertebrates (ed. Starck, J. M. \& Wang, T.), Enfield, NH, USA, Science Publishers, 2005. pp. 175-200.

Storer, T. I.; Usinger, R. L.; Stebbins, R. C. \& Nybakken, J. W. Zoologia Geral. 6a . São Paulo, Companhia Editora Nacional, 1986. pp. 816.

Skoczylas, R. Physiology of the digestive tract. In: Gans, C, Gans, K. A. (ed.) Biology of the reptilia. London, Physiology Academic Press., 1978. pp. 589-717. V. 8.

Theodoropoulos, D. S. \& Ledford, D. K. Is GERD a factor in your patient's asthma? gastroesophageal reflux disease. J. Respir. Dis., 21:238-52, 2000.

Uriona, T. J.; Farmer, C. G.; Dazely, J.; Clayton F. \& Moore, J. Structure and function of the esophagus of the American alligator (Alligator mississippiensis). J. Exp. Biol., 208:3047-53, 2005.

Wallach, J. D. Environmental and nutritional diseases of captive reptiles. J. Am. Vet. Med. Assoc., 159(11):163243, 1971.

Correspondence to:

Mariluce Ferreira Romão

Laboratory for Teaching and Research on Wild Animals limpets

Faculty of Veterinary Medicine

Federal University of Uberlandia

BRAZIL

Email: mariluce_educa@hotmail.com
Received: 04-11-2010 Accepted: 24-11-2010 